\title{
The Nordic Criminal Law Doctrine in a European Setting - Challenges and Potential
}

\author{
DAN FRÄNDE *
}

\section{$1 \quad$ Introduction}

This brief article is based on personal experience from teaching and developing Finnish criminal law doctrine. At the same time some comparison will be made with other Nordic states, as the situation in these is somewhat similar. The point of view in this article is internal, which can be described with the following metaphor: I participate in the game of football, but also expect there to be other players and spectators that are interested in the game.

I should here point out, that my remarks regarding the research on criminal law do not necessarily apply for the research on criminal procedural law. In the field of Finnish legal science and legislation, the Swedish legislation development and legal science are closely followed. For example the German discussion on criminal procedural law is barely taken into account at all. Unfortunately, the legal development in Norway and Denmark is not that focused upon in Finnish legislation development either. It is unclear how much the other Nordic states are influenced by each other as regards criminal procedural law. It can further be noted that the Finnish civil procedural law is equally inspired by the Swedish situation, as is the case for criminal procedure.

\section{What is the aim of criminal law doctrine?}

The purpose of criminal law doctrine is to make criminal law systems more rational and predictable. ${ }^{1}$ I primarily refer to the efforts of researchers to systematise the law and to construct a general part. ${ }^{2}$ The general part of criminal law is what would in German be

Professor of criminal law and criminal procedural law, Faculty of law, University of Helsinki.

On the character of legal dogmatics, see Jareborg, Rättsdogmatik som vetenskap, Svensk Juristtidning 2004 pp. 1-10.

2 A strong position for system thinking within legal science is given by Pawlik, Das Unrecht des Bürgers (Tübingen 2012) especially pp. 1-23. 
called 'Allgemeine Lehren'. All researchers within the field of criminal law do not need to publish books on issues relating to the general part, but what they do need, is a good understanding of the system as a whole. A strong awareness of the system is required for an understanding of how the system functions.

The research actually conducted in the Nordic countries does not solely focus on systematisation. Naturally researchers also interpret the law.

The formation of various concepts is a central task assigned to researchers in criminal law. Effective and well-reasoned concepts are vital both in relation to the systematisation and the interpretation of law. I regard them mainly as tools. And as we know, some tools are better than others.

\section{The limits of a fully national criminal law doctrine}

There is, at least in principle, nothing that prevents us, as researchers in criminal law, to stick to our national legal system. This might to some extent be justified if the general part of criminal law has recently been revised, as is the case in Finland. ${ }^{3}$ In Norway, new rules will also enter into force some day. ${ }^{4}$

The temptation to take a very narrow view and only focus on the national legal system is considerable, if the researcher has participated in drafting the rules that form the new general part of criminal law.

This type of isolated approach, with a focus only on national law, can be seen as practically oriented. It does not fulfil the criteria of 'jurisprudence' (Rechtswissenschaft); or at least it does not fulfil the requirements set forth by the University of Helsinki. According to our criteria, a thesis has to make reference to - and I quote - 'a sufficient expertise in the research field. The problem in Finland is that we do not have enough experts in criminal law. ${ }^{5}$

Consequently, it is not possible to write a $\mathrm{PhD}$ thesis of that nature in Finland. The situation is different in larger countries, such as Germany. This becomes obvious when studying German $\mathrm{PhD}$ dissertations and habilitations.

Research can be conducted on specific crimes, as for example tax offences, insider trading, offences against bankruptcy laws, money laundering etc. However - and I really want to emphasise this - the research needs to be based on solid knowledge of the general part of criminal law.

3 See e.g. Matikkala, Om slutskakning - den finska strafflagsrevisionens sista fas, in Laitinen(ed.): Nordisk Workshop för Straffrätt (Rovaniemi 2007) pp. 101-110.

4 The amended Norwegian Criminal Code, Lov om straff (straffeloven) Act 20. May 2005 has yet not entered into force.

5 The personal gallery of the Finnish criminal law science has been thoroughly dealt with in Finnish by Lahti, Rikosoikeustiede ja rikosoikeuden yleiset opit - kehityssuuntia 1960-luvulta 2010-luvulle, in Lahti (ed.) Rikosoikeuden muutos 1960-luvulta 2010-luvulle. Pekka Koskisen (1943-2011) muistojulkaisu (Helsinki 2013), pp. 53-68. 
The criminal law doctrine is in other words based on other sources than national preparatory works and case law. This is a view that we, as researchers, should have as a starting point.

The criminal law doctrine is developed within a jurisprudence that defines its own rules. The jurisprudence also differentiates between good and poor research. There are potentially differences between the Nordic countries in how the rules are defined. Today I will not discuss further to what extent this would be the case.

What I proclaim, is that the Nordic scientific criminal law doctrine utilises sources of foreign origin. For example, in Finland it is common for the authors to turn to Nordic sources. In my experience there is a similar trend among $\mathrm{PhD}$ students in other Nordic countries. They refer to Nordic legislation and statements in the doctrine. The decision to write in Finnish will make it more difficult for the author to take part in the scientific discussion.

The problem we face today is not so much related to the availability of sources. On the contrary, we struggle because of the great number and variety of sources.

Nowadays, most $\mathrm{PhD}$ theses in criminal law and criminal procedural law have several links to international sources. Both international conventions and material produced by the EU have an effect on this field of law. For example, it would be impossible to write a Nordic PhD thesis on insider trading, without taking notice of the numerous conventions and EU norms on the basis of which the rules in the Finnish Penal Code have been stipulated. ${ }^{6}$ These are sources of law that need to be taken into consideration in a scientific text. In contrast, it would be normal for a Finnish judge to only read the preparatory works when applying rules that are based on EU norms. They rarely study the directive or the framework decision that has been adopted on EU level.

In my opinion, texts on the general part of criminal law have a similar status. The 'grammar' of criminal law is universal. Hence, researchers are forced to pay regard to texts written outside the Nordic countries. An analogy could perhaps be made to the rules on evidence: the best evidence should always be noted. Taking this analogy further, we recall that rational models and patterns of thought are of relevance when analysing the rules on evidence. These patterns of thought can normally be found in judicial systems of larger countries. Nowadays these countries would mainly be Germany and the Anglo-Saxon countries, like England, Wales and the US. The discussion on the legitimation of criminal legislative acts has been most active in the Anglo-Saxon countries, whereas the German doctrine has focused more on the concept of crime and its components. 


\section{Can Europe learn from the Nordic criminal law doctrine?}

We are well justified in presuming that the Nordic criminal law doctrine, with scientific ambitions, also makes use of European sources. This type of Nordic research can only participate in the debate on European level by publishing in English or German.

It is obviously hard for the researchers to avoid the national judicial system if they focus on the general part of criminal law. In that case, the research will consequently be of less interest for the international academic community.

Worth noticing is that e.g. Jareborg published research on the objective requirements of negligence in English. ${ }^{7} \mathrm{He}$ was able to make a thorough analysis, without discussing the Swedish national judicial system too extensively.

Research on questions relating to criminal law philosophy will not share these challenges. The link to a national judicial system is almost irrelevant. This would be the case for example when dealing with theory on criminalisation or the general legitimation of criminal law.

\section{Is a criminal law doctrine with European influence of any practical relevance?}

I can immediately come to think of one way that the doctrine has a large impact. Namely, it will affect the education in criminal law that is offered to students. Many researchers that tackle fundamental questions in their work give lectures at universities. Naturally, they will present their ideas during those lectures. In the long run we may expect this to initiate changes and that this will result in better case law.

Sometimes concrete cases linked to the general part of criminal law need to be solved through case law. Does the academic discussion have any significance under such circumstances? Is there a genuine dialogue between science and praxis?

I don't have any clear cut answers to these questions. However, I should mention two phenomena.

The first relates to criminal intent. We could start with the Finnish model. For several decades students could read in the leading Finnish textbook that dolus eventualis in crimes where the harm is actually realised requires that the suspect is aware of a possible consequence and is at least indifferent toward this consequence. The Supreme Court of Finland was, however, reluctant to accept this. ${ }^{8}$

The change came in 1978 when a type of 'probability intent' was introduced by the Supreme Court in a few judgements, without providing any real justification for this model. There had been no interaction between the court and the research community.

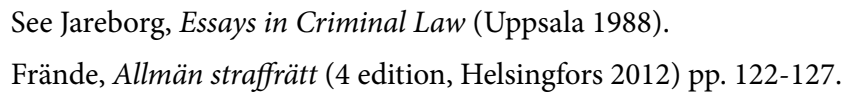


A discussion on these issues had not taken place in the academic world at that time and apparently there was resistance to the use of foreign sources.

The research would increase radically in the 80's and the problems related to the use of a model based on 'probability intent' were revealed. Later, a committee was established in order to prepare a thorough reform of the general part of criminal law in Finland. The committee, led by professor Pekka Koskinen, put forward a proposal, that did not only accept the concept of 'probability intent', but also introduced the concept of 'intent of acceptation'. Koskinen had excellent knowledge of foreign criminal law systems and could therefore base the proposal on comparative law analysis.

In a statement on the proposal, the Supreme Court decided not to engage itself in a scientific discussion on intent. Instead the court claimed that it had been presented with no arguments that would justify the 'intent of acceptation'. The Parliament accepted the reasoning of the Supreme Court. Hence, we still only have 'probability intent' mentioned in the legislation. ${ }^{9}$

Personally, I regard this as no more than a stubborn attempt to stick to an old tradition dating back to 1978. In my opinion the Supreme Court ignored the results of legal research. These results had mainly been obtained through the analysis of foreign sources. There appears to be some twisted nationalism, which may have affected the manner in which the Supreme Court decided to handle the question of intent.

The legal science did not give up and the discussion has continued. The Supreme Court has not amended its position and sticks to the old 'probability intent'. This has been the case, despite the fact that the Parliament in relation to other components than consequences did not rule out the possibility to apply 'intent of acceptation'. The Supreme Court appears to fight a round of shadowboxing against the doctrine.

The Swedish version of dolus eventualis was the target of criticism during many years in Sweden. Dolus eventualis was called hypothetical eventual intent. The Supreme Court of Sweden confronted the issue in two important judgements in 2002 and $2004 .^{10}$ The court solved the cases with the help of a type of 'intent of indifference.' I will not go into detail about the exact structure of this model. ${ }^{11}$ What is of interest is that the Supreme Court of Sweden in a sense participates in the doctrinal discussion. The court listens to the discussion in the criminal law doctrine and then, with its status as an authority, delivers an answer. Naturally, this will not silence the discussion in the doctrine but case law has to adapt to the new guidelines.

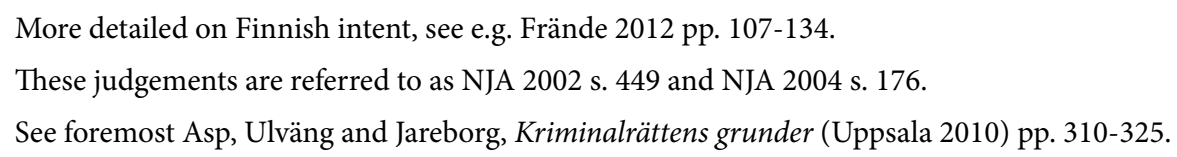


The second example I would like to present concerns culpa of fault, or in German: objektive Zurechnung. ${ }^{12}$ The discussion in Finland was very much influenced by Jareborg's ideas in 'Two Faces of Culpa. ${ }^{13}$ Initially, when writing my thesis in 1989, I expressed my scepticism. However, by 1994, when publishing a textbook, I had already become a true believer and supported the ideas of Jareborg. ${ }^{14}$ The model has been intensively discussed in the Finnish criminal law doctrine. The debate reached its peak in 1996, with the publication of a thesis on punishable negligence by Nuutila. ${ }^{15}$

Concepts such as permissible and unauthorised risk as well as culpa of fault are mentioned in the preparatory works in relation to the rules on negligence in chapter 3 section 7 in the Finnish Penal Code. In contrast, the Supreme Court of Finland has deemed it sufficient to work with the concept of predictability. However, nothing indicates that the court would find culpa of fault to be relevant. Naturally, we feel intrigued to speculate on the reasons behind this. Personally, I believe that the Finnish tort law has had its influence. When determining the limitations of liability, the predictability of the damage is of vital importance. Most Finnish judges will take on both civil and criminal cases. Hence, they probably see no reason to divert from the theory on predictability as they turn to a criminal case. It seems like 'objective Zurechnung' will not be applied in Finnish courts as long as the objective and the subjective aspects are not differentiated in tort law.

I do not dear to comment on the attitude of the Swedish Supreme Court toward the doctrine of culpa of fault.

All in all, I wish to emphasise that the Nordic criminal law research is heavily dependent on European sources. To what extent Nordic researchers might influence the rest of Europe is a trickier question.

It appears that at least in Finland the case law is fairly immune against impulses from the criminal law doctrine.

12 Frände, Objektive Zurechnung - nichts für Finnland, in Freund, Murmann, Bloy and Perron (eds.) Grundlagen und Dogmatik des gesamten Strafrechtssystems Festschrift für Wolfgang Frisch zum 70. Geburtstag (Ducker \& Humblot 2013) pp. 271-280.

13 See Jareborg 1988.

14 See Frände, Den straffrättsliga legalitetsprincipen (Ekenäs 1989) p. 196 and Frände, Allmän straffrätt (Helsingfors 1994) pp. 103-116.

15 See Nuutila, Rikosoikeudellinen huolimattomuus (Vantaa 1996). On the thesis in Swedish, see Frände in JFT (Juridisk Tidskrift published by Juridiska Föreningen in Finland) 1997 pp. 213-222. 